\title{
PENERAPAN MODEL PEMBELAJARAN PROBLEM BASED LEARNING UNTUK MENINGKATKAN PROSES DAN HASIL BELAJAR MUATAN IPA TEMA 8 SUB TEMA 1 KELAS 4
}

\author{
Anggistia Febby Fravitasari ${ }^{1}$, Nyoto Harjono ${ }^{2}$, Gamaliel Septian Airlanda ${ }^{3}$ \\ 1,2,3 Jurusan Pendidikan Guru Sekolah Dasar, FKIP \\ Universitas Kristen Satya Wacana \\ Jawa Tengah, Indonesia \\ email : anggistiafebby29@gmail.com¹ , har.john59@gmail.com², \\ gama.airlanda@staff.uksw.edu ${ }^{3}$
}

\begin{abstract}
Abstrak
Penelitian ini bertujuan untuk meningkatkan proses dan hasil belajar muatan IPA siswa kelas 4 pada Tema 8 Sub Tema 1 melalui model pembelajaran Problem Based Learning. Penelitian ini merupakan penelitian tindakan kelas (PTK). Penelitian ini dilaksanakan dalam dua siklus dengan tiga pertemuan setiap siklusnya. Subjek penelitian adalah siswa kelas 4 SDN Mangunsari 05. Teknik pengumpulan data yang digunakan dalam penelitian tindakan kelas ini yaitu tes, observasi, dan dokumentasi. Hasil uji validitas pada siklus I dari 45 soal ada 26 soal yang valid, pada siklus II ada 24 soal yang valid. Uji reliabilitas pada siklus I diperoleh nilai Cronbach's Alpha sebesar 0,904 dan pada siklus II diperoleh nilai Cronbach's Alpha sebesar 0,878. Proses pembelajaran pada kondisi awal tindakan guru sebesar $78,57 \%$ dan tindakan siswa sebesar $71,42 \%$. Pada siklus I tindakan guru dalam proses pembelajaran pertemuan pertama $82,14 \%$, pertemuan kedua sebesar $89,28 \%$. Tindakan siswa pada siklus I pertemuan pertama sebesar $75 \%$ dan pertemuan kedua sebesar $89,28 \%$. Pada siklus II tindakan guru pertemuan pertama sebesar $100 \%$ dan pertemuan kedua $100 \%$. Tindakan siswa dalam proses pembebelajaran pertemuan pertama sebesar $92,85 \%$ dan pertemuan kedua $100 \%$. Hasil penelitian menunjukkan adanya peningkatan hasil belajar muatan IPA khususnya tema 8 sub tema 1. Hal ini dibuktikan dengan adanya peningkatan perolehan hasil belajar. Pada saat kondisi awal sebesar $30 \%$ siswa yang mencapai batas tuntas. Pada siklus I terjadi peningkatan menjadi $80 \%$ yang mencapai ketuntasan. Sedangkan pada siklus II terjadi peningkatan menjadi 100\% yang mencapai ketuntasan. Kesimpulan dalam penelitian ini adalah penerapan model pembelajaran PBL membuat siswa menjadi lebih aktif dan berani dalam menyelesaikan masalah dan meningkatkan hasil belajar muatan IPA.
\end{abstract}

Kata Kunci : Model PBL, Proses, Hasil Belajar

\section{Abstract}

This study aims to improve the process and the results of learning content of science grade 4 students on the theme 8 Sub Theme 1 through the model of learning Problem Based Learning. This research is a classroom action research (PTK). The study was conducted in two cycles with three meetings each cycle. The subjects of the study were 4th grade students of SDN Mangunsari 05. The data collection techniques used in this classroom action research were test, observation, and documentation. Result of validity test at cycle I of 45 problem there are 26 valid questions, in cycle II there are 24 valid questions. Reliability test in cycle I obtained Cronbach's Alpha value of 0.904 and on the second cycle obtained Cronbach's Alpha value of 0.878 . The learning process on the initial condition of teacher action is $78,57 \%$ and student action equal to $71,42 \%$. In the first cycle of teacher action in the learning process of the first meeting $82.14 \%$, the second meeting amounted to $89.28 \%$. Student action on first cycle of first meeting is $75 \%$ and second meeting is $89.28 \%$. In cycle II the teacher's first meeting action is $100 \%$ and the second meeting is $100 \%$. Student actions in the first meeting process of learning amounted to $92.85 \%$ and the second meeting 100\%. The result of the research shows that there is an increase of learning outcome of IPA especially the theme of 8 sub themes 1. It is proved by the increasing of learning result. At the time of initial condition of $30 \%$ of students who reach the threshold. In the first cycle there was an increase to $80 \%$ that reached completeness. While in the second cycle there is an increase to $100 \%$ which reached completeness. The conclusion of this research is the application of PBL learning model to make students become more active and courageous in solving problems and increasing the result of studying the content of science.

Keywords: PBL Model, Process, Learning Outcomes 


\section{Pendahuluan}

Pendidikan merupakan salah satu cara untuk membentuk suatu proses pembelajaran dan pengembangan diri baik secara fisik maupun non fisik yang mampu diterapkan di kehidupan sehari - hari baik keluarga, masyarakat, bangsa dan negara. Perkembangan globalisasi berpengaruh pada kurikulum yang digunakan di Indonesia. Kementerian Pendidikan dan Kebudayaan RI telah mengganti kurikulum tingkat satuan pendidikan menjadi kurikulum 2013. Sesuai dengan standar kompetensi lulusan mengenai kurikulum 2013, tujuan pembelajaran mencakup pengembangan ranah sikap, pengetahuan, dan keterampilan. Kurikulum 2013 proses pembelajaran dilaksanakan secara interaktif, inspiratif, menyenangkan, menantang, memotivasi siswa untuk berpartisipasi aktif, serta memberikan ruang yang cukup bagi kreativitas dan kemandirian yang sesuai dengan bakat, minat dan perkembangan fisik serta psikologis siswa (Permendikbud No 65, 2013).

Berdasarkan hasil observasi dan wawancara dengan guru kelas 4 di SDN Mangunsari 05, permasalahan yang timbul adalah siswa kelas 4 masih terlihat kurang aktif saat proses pembelajaran. Hal ini terlihat pada saat proses pembelajaran berlangsung, guru meminta siswa untuk bertanya mengenai materi yang belum dipahami oleh siswa namun hanya terdapat 5 10 siswa yang bertanya. Siswa juga kurang aktif dalam menjawab pertanyaan yang diberikan oleh guru, hal ini karena siswa merasa takut salah dan malu saat ingin mengutarakan pendapatnya sendiri. Saat guru menerangkan materi yang diajarkan siswa merasa jenuh. Sehingga bermain sendiri dengan teman duduk ataupun teman yang di dekatnya dan siswa kurang fokus dalam memperhatikan penjelasan dari guru. Guru melakukan kegiatan kelompok bertujuan memberikan kesempatan kepada siswa untuk saling bertukar pikiran antar anggota kelompok maupun kelompok lainnya, namun siswa masih pasif. Rendahnya aktivitas belajar siswa yang kurang aktif dalam proses pembelajaran berpengaruh pada rendahnya hasil belajar muatan IPA siswa kelas 4 di SDN Mangunsari 05 yang belum mencapai Kriteria Ketuntasan Minimal $(\mathrm{KKM}=70)$. Di kelas $4 \mathrm{ini}$, pada kondisi awal ada 28 siswa dari jumlah keseluruhan 40 siswa yang mendapatkan nilai dibawah KKM. Berdasarkan temuan tersebut, terlihat jelas bahwa siswa kelas 4 yang sudah mencapai ketuntasan muatan IPA hanya $30 \%$.

Berdasarkan pada permasalahan tersebut untuk meningkatkan hasil belajar muatan IPA kelas 4 SDN Mangunsari 05 maka diperlukan upaya untuk perbaikan dalam kegiatan proses pembelajaran. Siswa harus lebih berperan aktif dalam proses pembelajaran. Hal tersebut selain untuk dapat meningkatkan hasil belajar muatan IPA juga siswa dapat memahami materi dengan menemukan sendiri pengetahuannya. Untuk mengendalikan permasalahan kurangnya keaktifan siswa dan rendahnya hasil belajar muatan IPA siswa kelas 4 SDN Mangunsari 05, peneliti menawarkan solusi dengan menerapkan model pembelajaran PBL dalam muatan IPA.

Upaya memperbaiki proses dan hasil belajar muatan IPA sangat perlu dilakukan. Salah satu cara untuk memperbaiki proses dan hasil belajar muatan IPA dengan menggunakan salah satu model pembelajaran yaitu model pembelajaran Problem Based Learning (PBL). Menurut Edwards dan Hummer (2011) model berbasis masalah merupakan model pembelajaran yang memfokuskan hubungan antara teori dengan praktek. Dapat diartikan bahwa pembelajaran diawali dengan suatu masalah yang berkaitan dengan kehidupan sehari - hari siswa, yang selanjutnya diterapkan dalam sebuah praktek percobaan untuk membuktikan permasalahan tersebut. Dalam model pembelajaran PBL ini siswa ditekankan untuk berpikir aktif, sedangkan guru hanya sebagai fasilitator dalam proses pembelajaran.

Menurut Shoimin (2014) Problem Based Learning merupakan model pembelajaran yang mampu melatih dan meningkatkan kemampuan untuk memecahkan masalah yang berpusat pada masalah nyata dari kehidupan yang konkret. PBL juga mampu mengembangkan aktivitas ilmiah siswa melalui diskusi kelompok. Sedangkan menurut Arends (2008) Problem Based Learning merupakan pembelajaran yang menampilkan berbagai masalah yang nyata, sehingga berfungsi sebagai batu lompatan untuk penyelidikan. Masalah yang suguhkan merupakan masalah yang dialami oleh siswa dalam kehidupan sehari - hari.

Dari beberapa pendapat ahli dapat disimpulkan bahwa model Problem Based Learning adalah model pembelajaran yang berbasis masalah, dimana pembelajaran ini memberikan 
masalah yang nyata atau yang dialami oleh siswa, kemudian siswa menyelesaikan atau memecahkan masalah tersebut secara mandiri maupun kelompok, sehingga mampu menemukan sendiri pengetahuannya. Siswa juga dapat berpikir aktif dalam proses pembelajaran.

Menurut Sugiyanto (2008) ada 5 langkah model pembelajaran Problem Based Learning sebagai berikut (1) Memberikan orientasi tentang permasalahannya kepada siswa, (2) Mengorganisasikan siswa untuk meneliti, (3) Membantu investigasi mandiri dan kelompok, (4) Mengembangkan dan mempresentasikan hasil, (5) Menganalisis dan mengevaluasi proses mengatasi masalah.

Hal penelitian yang relevan terkait dengan penelitian ini yaitu penelitian yang dilakukan oleh Riana Rahmasari tahun 2016 menyatakan bahwa penerapan model PBL dapat meningkatkan hasil belajar IPA. Pada prasiklus ketuntasan mata pelajaran IPA sebesar 58,33\% berjumlah 14 siswa yang mempunyai nilai lebih besar atau sama dengan 65 (KKM), sedangkan 10 siswa mendapat nilai dibawah KKM sebesar 41,67\%. Siklus 1 mempunyai ketuntasan sebesar 95,83\% yang berjumlah 23 siswa dan hanya satu siswa saja yang nilainya dibawah KKM. (Rahmasari, 2016)

Hasil penelitian relevan yang kedua yaitu hasil penelitian yang telah dilakukan oleh Dede Dewantara melalui penelitian tindakan kelas yang berjudul "Penerapan Model Pembelajaran Problem Based Learning Untuk Meningkatkan Aktivitas Dan Hasil Belajar Siswa Pada Pelajaran IPA (Studi Pada Siswa Kelas 5 SDN Pengambang 6 Banjarmasin)" menunjukan bahwa kegiatan siswa dalam proses pembelajaran baik siklus I dan siklus II terjadi peningkatan aktivitas siswa, dimana banyak siswa yang semakin aktif dalam belajar. Pada siklus I pertemuan I belum ada siswa yang sangat aktif, sedangkan pada pertemuan II 4 anak dan 5 anak pada pertemuan III. Pada siklus II mengalami peningkatan di pertemuan I sebanyak 6 orang, pada pertemuan II sebanyak 10 orang, dan pertemuan II menjadi 11 orang yang aktif. Hasil belajar muatan IPA pada siklus pertama ketuntasan belajar klasikal sebesar $60 \%$, sedangkan pada siklus kedua mengalami peningkatan hasil belajar yang mencapai $85 \%$ (Dewantara, 2014). Persamaan dari dua penelitian yang relevan adalah sama - sama menggunakan model pembelajaran PBL. Perbedaan pada dua penelitian yang relevan yaitu subjek penelitian, setting penelitian.

Berdasarkan uraian dan pertimbangan diatas untuk meningkatkan proses dan hasil belajar muatan IPA siswa tersebut peneliti tertarik untuk menerapkan model PBL dalam proses pembelajaran. Tujuan dari penelitian ini adalah sebagai berikut : 1) Menerapan model Problem Based Learning dalam meningkatkan proses pembelajaran muatan IPA tema 8 sub tema 1 Kelas 4 SD Negeri Mangunsari 05 Kecamatan Sidomukti Kota Salatiga Semester II Tahun 2017/2018, 2) Meningkatkan hasil belajar muatan IPA tema 8 sub tema 1 Kelas 4 SD Negeri Mangunsari 05 Kecamatan Sidomukti Kota Salatiga Semester II Tahun 2017/2018 melalui peningkatan proses pembelajaran melalui model Problem Based Learning.

\section{Metode}

Dalam penelitian ini subjek penelitian adalah siswa kelas 4 SD Negeri Mangunsari yang berjumlah 40 siswa. Terdiri dari 22 siswa laki-laki dan 18 siswi perempuan dengan latar belakang yang berbeda-beda. Mayoritas siswa berasal dari lingkungan sekitar sekolah. Sedangkan untuk objek penelitian dalam penelitian ini tindakan kelas ini adalah model pembelajaran PBL, proses dan hasil belajar muatan IPA siswa kelas 4 SDN Mangunsari 05. Penelitian ini berbentuk penelitian tindakan kelas. Menurut Mohammad Asrori penelitian tindakan kelas adalah suatu pencermatan terhadap kegiatan belajar berupa tindakan, yang disengaja dimunculkan dan terjadi dalam sebuah kelas secara bersama. Dikategorikan sebagai bentuk penelitian tindakan kelas karena penelitian ini berupa suatu tindakan untuk mengatasi masalah terkait kegiatan belajar mengajar disuatu kelas dengan pendekatan deskriptif kualitatif dan deskriptif komparatif. Deskriptif komparatif membandingkan antara hasil kondisi awal, siklus I, dan siklus II untuk mengetahui peningkatan hasil belajar kognitif siswa. Sedangkan deskriptif kualitatif merupakan hasil penelitian menggunakan kualitas tanpa mengukurnya 
dengan angka - angka hasil perhitungan sebagai tolak ukur keberhasilannya. Deskriptif kualitatif diperoleh dari lembar observasi proses pelaksanaan pembelajaran.

Penelitian ini menggunakan model spiral menurut Kemmis dan Taggart (Zainal Aqib, 2006:22) meliputi "tahap perencanaan, pelaksanaan, tindakan dan observasi, refleksi. Prosedur penelitian dilakukan dalam dua siklus yaitu siklus I dan siklus II dan direncanakan dengan menggunakan langkah-langkah : perencanaan, tindakan dan observasi, serta refleksi. Berikut merupakan prosedur pelaksanaan menurut Kemmis dan Taggart :

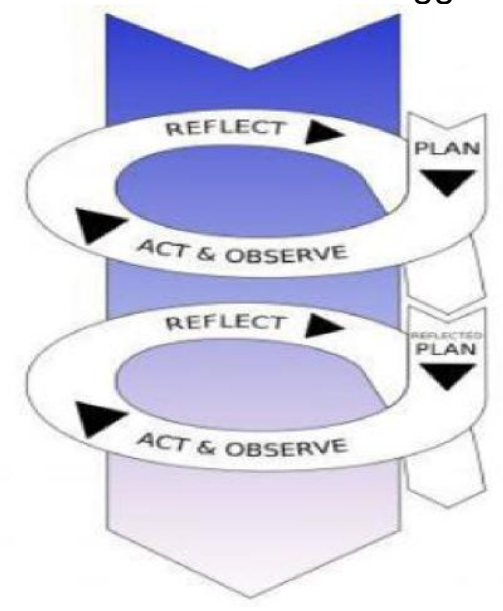

Gambar 1. Prosedur Penelitian Menurut Kemmis dan Taggart

Dalam tahap observasi menggunakan lembar instrumen observasi guru dan lembar observasi siswa yang telah dibuat sesuai dengan sintaks model pembelajaran PBL. Sedangkan instrument pengumpulan data untuk mengukur hasil belajar muatan IPA berupa tes. Tes yang digunakan adalah tes objektif berbentuk pilihan ganda. Penggunaan tes pilihan ganda bertujuan untuk mencakup semua indikator dalam kompetensi dasar. Hasil uji validitas pada siklus I dari 45 soal ada 26 soal yang valid, pada siklus II ada 24 soal yang valid. Uji reliabilitas pada siklus I diperoleh nilai Cronbach's Alpha sebesar 0,904 dan pada siklus II diperoleh nilai Cronbach's Alpha sebesar 0,878.

\section{Hasil Dan Pembahasan}

Penelitian tindakan kelas ini dilaksanakan mulai tanggal 16 April 2018 sampai 27 April 2018. Penelitian ini dilaksanakan dalam 2 siklus, dalam setiap siklus dilaksanakan selama 3 kali pertemuan. Untuk 2 kali pertemuan pemberian tindakan dan 1 kali pertemuan digunakan untuk tes hasil belajar muatan IPA.

Pengamatan proses pembelajaran siswa dilakukan pada saat pelaksanaan tindakan. Data mengenai proses pembelajaran tindakan diperoleh melalui penilaian dengan menggunakan lembar observasi guru dan lembar observasi siswa. Lembar observasi menggunakan 7 indikator yaitu pendahuluan, memberikan orientasi tentang permasalahannya kepada siswa, mengorganisasikan siswa untuk meneliti, membantu investigasi mandiri dan kelompok, mengembangkan dan mempresentasikan hasil, menganalisis dan mengevaluasi proses mengatasi masalah, dan penutup. Berdasarkan hasil penelitian mengenai proses pembelajaran guru dan siswa dapat dilihat pada tabel berikut :

Tabel 1. Rekapitulasi Proses Pelaksanaan Tindakan Guru dan Siswa

\begin{tabular}{ccccccc}
\hline \multirow{2}{*}{ No } & \multirow{2}{*}{ Tindakan } & \multicolumn{2}{c}{ Kondisi } & Pertemuan I & \multicolumn{2}{c}{ Siklus II } \\
& & Awal & & & & \\
& & & & & \\
\hline 1 & Tindakan Guru & $78,57 \%$ & $82,14 \%$ & $89,28 \%$ & $100 \%$ & $100 \%$ \\
2 & Tindakan Siswa & $71,42 \%$ & $75 \%$ & $89,28 \%$ & $92,85 \%$ & $100 \%$ \\
\hline
\end{tabular}


Dari tabel diatas pada kondisi awal tindakan guru sebesar $78,57 \%$ dan tindakan siswa sebesar 71,425 . Pada siklus I pertemuan I tindakan guru dalam proses pembelajaran PBL mencapai $82,14 \%$ dan pertemuan II $89,28 \%$, sedangkan tindakan siswa pada siklus I pertemuan I dalam proses pembelajaran PBL mencapai $75 \%$ dan pertemuan II $89,28 \%$. Pada siklus I belum berjalan dengan baik, karena guru masih belum memahami langkah model PBL. Siswa juga masih kurang antusias mengikuti pembelajaran dan kurang memahami permasalahan yang diberikan guru. Pada siklus II pertemuan I tindakan guru dalam proses pembelajaran meningkat menjadi $100 \%$, juga pada pertemuan II $100 \%$. Sedangkan tindakan guru pada siklus II pertemuan II pada proses pembelajaran pada pertemuan I mengalami kenaikan menjadi 92,85\% dan pertemuan II menjadi 100\%.

Pengumpulan hasil belajar muatan IPA siswa diperoleh melalui pemberian tes berbentuk tes objektif pilihan ganda dengan banyak soal 45 soal. Pemberian tes hasil belajar muatan IPA dilaksanakan pada pertemuan ketiga setiap siklusnya. berikut :

Berdasarkan hasil penelitian mengenai hasil belajar muatan IPA dapat dilihat pada tabel

Tabel 2. Rekapitulasi Hasil Belajar Muatan IPA

\begin{tabular}{|c|c|c|c|c|c|c|c|}
\hline \multirow{2}{*}{ No } & \multirow{2}{*}{ Ketuntasan } & \multicolumn{2}{|c|}{ Kondisi awal } & \multicolumn{2}{|c|}{ Siklus I } & \multicolumn{2}{|c|}{ Siklus II } \\
\hline & & $\mathrm{F}$ & $\%$ & $\mathrm{~F}$ & $\%$ & $\mathrm{~F}$ & $\%$ \\
\hline 1 & Tuntas & 12 & 30 & 32 & 80 & 40 & 100 \\
\hline 2 & Tidak Tuntas & 28 & 70 & 8 & 20 & 0 & 0 \\
\hline \multirow[t]{2}{*}{3} & $\begin{array}{l}\text { Rata - Rata } \\
\text { hasil belajar }\end{array}$ & \multicolumn{2}{|c|}{63,25} & \multicolumn{2}{|c|}{76,73} & \multicolumn{2}{|c|}{85,95} \\
\hline & Jumlah & 40 & 100 & 40 & 100 & 40 & 100 \\
\hline
\end{tabular}

Berdasarkan pada tabel diatas diketahui bahwa rata - rata hasil belajar muatan IPA siswa kelas 4 pada kondisi awal sebelum perlakuan menggunakan model pembelajaran yaitu 63,25 , saat siklus I rata - rata yang diperoleh siswa menjadi 76,73 , dan pada siklus II terjadi peningkatan menjadi 85,95. Jumlah siswa yang tuntas pada kondisi awal yaitu 12 siswa dari 40 siswa, saat siklus I siswa yang tuntas menjadi 32 siswa, dan pada siklus II meningkat menjadi 40 siswa. Apabila dipersentasekan ketuntasan hasil belajar muatan IPA pada kondisi awal $30 \%$, siklus I $80 \%$, dan siklus II $100 \%$.

Pada saat kondisi awal, permasalahan yang dihadapi yaitu kurang aktifnya siswa pada proses pembelajaran, sehingga siswa kurang memahami pembelajaran IPA. Siswa kurang aktif dalam bertanya saat guru meminta siswa untuk bertanya mengenai materi yang belum dipahami. Hal ini disebabkan siswa merasa malu dan takut salah apabila mau bertanya. Saat guru menerangkan materi yang diajarkan siswa merasa jenuh Sehingga bermain sendiri dengan teman duduk ataupun teman yang di dekatnya dan siswa kurang fokus dalam memperhatikan penjelasan dari guru. Guru melakukan kegiatan kelompok bertujuan memberikan kesempatan kepada siswa untuk saling bertukar pikiran antar anggota kelompok maupun kelompok lainnya, namun siswa masih pasif. Dari permasalahan tersebut mengakibatkan pada hasil belajar muatan IPA rendah. Hasil belajar muatan IPA pada kondisi awal dari 40 siswa hanya 12 siswa atau sebesar 30\% yang tuntas. Sedangkan untuk rata rata hasil belajar muatan IPA yaitu sebesar 63,25. Melihat hasil pada kondisi awal yang belum mencapai KKM ( $\geq 70)$, akibat dari siswa yang kurang aktif, maka untuk mengatasi permasalahan tersebut dilaksanakan proses pembelajaran dengan menerapkan model PBL yang diyakini dapat mengatasi permasalahan tersebut.

Penelitian diawali dengan perencanaan. Pada tahap ini dilaksanakan dengan mempersiapkan materi dan sumber belajar yang akan digunakan. Selanjutnya, merancang rencana pelaksanaan pembelajaran (RPP) yang berorientasi pada sintaks model pembelajaran PBL. Membuat dan menyiapkan lembar kerja siswa yang digunakan siswa untuk melakukan percobaan. Menyiapkan perlengkapan belajar muatan IPA yang akan digunakan dalam 
percobaan sederhana. Menyiapkan dan membuat soal evaluasi setiap siklusnya. Menyusun dan menyiapkan lembar observasi guru dan siswa sebagai pedoman untuk pengamatan sikap guru maupun siswa.

Tahap yang kedua yaitu tahap tindakan. Pada tahap ini disesuaikan dengan standar proses pembelajaran yang meliputi pendahuluan, kegiatan inti, dan kegiatan penutup. Kegiatan pembukaan dilaksanakan dengan do'a bersama dan dilanjutkan dengan melakukan absensi juga menanyakan kabar siswa. Melakukan apersepsi dan menyampaikan tujuan pembelajaran yang akan dilaksanakan. Kegiatan inti dilaksanakan sesuai dengan langkah - langkah model PBL yaitu 1) memberikan orientasi tentang permasalahannya kepada siswa, 2) mengorganisasikan siswa untuk meneliti, 3) membantu investigasi mandiri dan kelompok, 4) mengembangkan dan mempresentasikan hasil, 5) menganalisis dan mengevaluasi proses mengatasi masalah. Kegiatan penutup meliputi kegiatan refleksi, menyampaikan materi selanjutnya dan berdo'a bersama.

Proses dan hasil belajar muatan IPA siswa yang ditingkatkan dengan menerapkan model pembelajaran PBL dilakukan dalam 2 siklus setiap siklus terdiri dari 3 pertemuan dan setiap pertemuan dilaksanakan dengan alokasi waktu 70 menit. Pada siklus I pertemuan pertama proses tindakan guru pada pembelajaran sebesar $82,14 \%$ dan tindakan siswa sebesar $75 \%$. Pada pertemuan pertama ini belum berjalan baik karena siswa belum melaksanakan proses pembelajaran sesuai dengan yang diharapkan siswa masih kurang antusias mengikuti pembelajaran pada pertemuan pertama, hal tersebut dapat dilihat saat kegiatan memperhatikan dan memahami permasalahan yang diberikan guru, saat kelompok lain maju kedepan masih ada siswa atau kelompok lain belum mendengarkan dan memberi tanggapan. Pada siklus I pertemuan kedua proses tindakan guru pada pembelajaran sebesar $89,28 \%$ dan tindakan siswa sebesar $89,28 \%$. Pada pertemuan kedua ini sudah meningkat, namun belum sesuai dengan yang diharapkan. Siswa masih belum antusias, hal tersebut dapat dilihat saat kegiatan menyimpulkan mengenai permasalahan yang telah diselesaikan.

Pada siklus I menunjukan ada peningkatan hasil belajar muatan IPA dari kondisi awal dengan perbandingan nilai yang tuntas sebanyak 32 siswa atau $80 \%$ sedangkan jumlah siswa yang mendapatkan nilai tidak tuntas sebanyak 8 siswa atau $20 \%$ dengan perolehan rata - rata adalah 76,73 kemudian perolehan nilai tertinggi adalah 89 dan perolehan nilai terendah adalah 65.

Meskipun perolehan nilai pada siklus I sudah menunjukkan peningkatan hasil belajar muatan IPA namun indikator hasil belum menunjukkan keberhasilan secara klasikal karena masih ada siswa yang mendapat nilai di bawah KKM. Pada siklus I masih terdapat kelemahan diantaranya : 1) siswa masih belum memahami langkah -langkah model pembelajaran PBL dengan benar pada pertemuan pertama, 2) tidak semua siswa memperhatikan dan memahami permasalahan yang diberikan oleh guru, 3) siswa juga belum menyimpulkan mengenai permasalahan yang telah diselesaikan.

Kelemahan - kelemahan pada siklus I digunakan sebagai acuan untuk melaksanakan siklus selanjutnya, yaitu kegiatan siklus II yang dilaksanakan sebagai tindak lanjut dan penyempurnaan dari siklus I yang dilaksanakan sama seperti kegiatan sebelumnya dengan 3 kali pertemuan dan setiap pertemuan alokasi waktu 70 menit. Hasil kegiatan siklus II yang dilaksanakan sebagai kegiatan tindak lanjut dan penyempurnaan dari siklus I diperoleh hasil belajar yang mengalami peningkatan dibandingkan dengan kegiatan siklus I.

Pada siklus II pertemuan pertama proses tindakan guru pada pembelajaran sebesar $100 \%$ dan tindakan siswa sebesar 92,85\%. Pada pertemuan pertama ini, guru sudah melaksanakan sesuai dengan yang diharapkan. Sedangkan siswa belum berjalan dengan baik karena masih ada siswa yang belum antusias dan aktif dalam mengikuti proses pembelajaran. Hal ini dapat dilihat saat siswa menganalisis dan mengevaluasi proses mengatasi masalah. Pada siklus II pertemuan kedua proses tindakan guru pada pembelajaran sebesar $100 \%$. Sehingga dalam pertemuan kedua ini sudah berjalan baik sesuai dengan harapan. Proses tindakan siswa sebesar $100 \%$. Sehingga dalam pertemuan ini siswa sudah melaksanakan pembelajaran sesuai dengan yang diharapkan. Siswa juga antusias dan aktif dalam mengikuti pembelajaran. 
Peningkatan hasil belajar pada siklus II dapat diketahui dengan perolehan nilai siswa kelas 4 mendapatkan ketuntasan $100 \%$ karena dari hasil nilai 40 siswa kelas 4 SDN Mangunsari 05 pada siklus II sudah mencapai KKM (>70) yang ditetapkan dan perolehan nilai rata - rata siswa adalah 85,95 dengan perolehan nilai tertinggi adalah 100 dan perolehan nilai terendah adalah 76 .

Peningkatan ini terjadi karena dalam proses pembelajaran yang mengimplementasikan model PBL. Langkah - langkah dalam model pembelajaran PBL menekankan pada kemampuan siswa untuk mengembangkan kemampuan mandiri maupun kelompok. Siswa juga akan aktif dalam proses pembelajaran. Pada model ini siswa akan bertukar pikiran dan menemukan sendiri pengetahuannya sehingga siswa tidak malu dalam bertanya maupun menjawab pertanyaan guru.

Berdasarkan hasil penelitian diatas membuktikan bahwa guru tepat memilih model pembelajaran. Hal ini sependapat dengan temuan peneliti lain seperti yang dilakukan oleh Suwandi (2015) menyatakan bahwa model pembelajaran PBL dapat meningkatkan hasil belajar siswa dan proses pembelajaran yang kondusif, aktif, kreatif, dan menyenangkan pada pembelajaran hubungan makhluk hidup dalam ekosistem. Wahyudi (2013) penggunaan model pembelajaran PBL dan word square dapat meningkatkan aktivitas siswa, aktivitas guru, dan hasil belajar konsep sifat -sifat cahaya pada siswa kelas V SDN Pemurus Dalam 7 Banjarmasin. Indah (2015) menyatakan bahwa model pembelajaran PBL dapat meningkatkan prestasi belajar IPA materi pokok sumber energi gerak pada siswa kelas IA SDN 9 Kabangka Tahun ajaran 2014/2015. Menurut Syafriana (2016) penerapan model pembelajaran PBL dalam pendekatan saintifik meningkatkan hasil belajar siswa pada pelajaran IPA kelas 5 SDN Surabaya. Hidayat (2016) menyatakan bahwa model pembelajaran PBL meningkatkan hasil belajar siswa kelas 5B SDN 1 Cakranegara tahun ajaran 2015/2016.

Berdasarkan penelitian yang telah dilakukan hasil penelitian dengan menggunakan model pembelajaran PBL pada muatan IPA siswa kelas 4 SDN Mangunsari 05 Salatiga telah berhasil karena kriteria dan tujuan yang diharapkan sudah tercapai yaitu adanya peningkatan proses dan hasil belajar muatan IPA. Hal ini terbukti dari rata - rata hasil belajar muatan IPA pada siklus dua mengalami kenaikan. Rata - rata hasil belajar muatan IPA siswa mencapai 85,95 dengan ketuntasan belajar sebesar $100 \%$. Model pembelajaran PBL merupakan model yang cocok bagi siswa, mengingat model ini membuat siswa menjadi aktif dan berani dalam mengutarakan pendapat.

\section{Simpulan dan Saran}

Berdasarkan hasil temuan dan pembahasan dalam penelitian ini, maka dapat disimpulkan penerapan model Problem Based Learning dapat meningkatkan proses dan hasil belajar muatan IPA tema 8 sub tema 1 Kelas 4 SD Negeri Mangunsari 05 Kecamatan Sidomukti Kota Salatiga Semester II Tahun 2017/2018. Hal ini terlihat dari adanya peningkatan hasil belajar muatan IPA siswa setiap siklusnya. Pada siklus I persentase hasil belajar muatan IPA adalah $80 \%$, sedangkan pada siklus II adalah $100 \%$.

Saran yang dapat disampaikan dalam penelitian ini adalah bagi siswa hendaknya aktif dalam kegiatan pembelajaran dan jangan takut untuk bertanya. Sedangkan bagi guru hendaknya menggunakan strategi yang sesuai dengan kebutuhannya dan memperdalam pemahaman mengenai model pembelajaran, guna untuk menyempurnakan proses pembelajaran agar dapat meningkatkan hasil belajar muatan IPA siswa.

\section{Daftar Rujukan}

Arends, Richard I. 2008. Learning to Teach. Yogyakarta: Pustaka Pelajar.

Asrori, Mohammad. 2012. Penelitian Tindakan Kelas, Bandung: CV Wacana Prima. 
Aqib, Zainal. 2006. Penelitian Tindakan Kelas. Bandung: Cv. Yrama Widya.

Dewantara, D. (2014). Penerapan Model Pembelajaran Problem Based Learning Untuk Meningkatkan Aktivitas Dan Hasil Belajar Siswa Pada Pelajaran IPA (Studi Pada Siswa Kelas V SDN Pengambangan 6 Banjarmasin). Jurnal Paradigma Volume 11 Nomor 2 Juli 2016, 41 - 44.

Edwards, S. dan Hummer, M. (2007). Journal Internasional. Problem Baseb Learning in Early Chilhood and Primary Pre-Service Teacher Education: Identifying the Issues and Examining the Benefits. Diunduh pada tanggal 06 Desember 2012 dari http/:ro.ecu.edu.au/ajte/vol32/iss2/3.

Hidayat, W. (2016). Penerapan Model Problem Based Learning Untuk Meningkatkan Hasil Belajar Ipa Siswa Kelas Vb Sdn 1 Cakranegara Tahun Ajaran 2015/2016. 1 - 14.

Indah, N. (2015). Meningkatkan Prestasi Belajar IPA Materi Pokok Sumber Energi Gerak Melalui Penerapan Model Pembelajaran Problem Based Learning (PBL) Pada Siswa Kelas I.A SD Negeri 9 Kabangka Tahun Ajaran 2014/2015. 50 - 55.

Permendikbud No 65 tentang Standar Proses. 2013.Jakarta.

Rahmasari, R. (2016). Penerapan Model Pembelajaran Problem Based Learning Untuk Meningkatkan Hasil Belajar IPA Kelas IV SD. Jurnal Pendidikan Guru Sekolah Dasar Edisi 36 Tahun ke 5 2016, 3456 - 3465.

Shoimin, A. (2014). 68 Model Pembelajaran Inovatif dalam Kurikulum 2013. Yogyakarta: ArRuzz Media.

Sugiyanto. 2008. Model-model Pembelajaran Inovatif. Surakarta: Panitia Sertifikasi Guru Rayon 13.

Suwandi, Y. (2015). Peningkatan Hasil Belajar IPA Tentang Ekosistem Melalui Metode Problem Based Learning Pada Siswa Kelas V Sekolah Dasar Kabupaten Tana Tidung. Jurnal Pendidikan Dasar Volume 6 Edisis 1 mei 2015, 93 - 102.

Syafriana, D. (2016). Penerapan Model Problem Based Learning (Pbl) Dalam Pendekatan Saintifik Untuk Meningkatkan Hasil. Jurnal Inovasi Pendidikan Dan Pembelajaran Sekolah Dasar, 30 - 43.

Wahyudi, M. D. (2013). Meningkatkan Hasil Belajar Konsep Sifat - Sifat Cahaya Menggunakan Model Pembelajaran Problem Based Learning (PBL) Dan Word Square Pada Siswa Kelas V SDN Pemurus Dalam 7 Banjarmasin. Jurnal Paradigma Volume 8 Nomor 1 Januari - Juni 2013, 1 -7. 